\title{
Digital constitutionalism: a new systematic theorisation
}

\author{
Edoardo Celeste \\ Sutherland School of Law, University College Dublin, Dublin, Ireland \\ Contact: edoardo.celeste@ucdconnect.ie
}

\begin{abstract}
Digital constitutionalism' is an appealing concept to explain the recent emergence of constitutional counteractions against the challenges produced by digital technology. However, the existing scholarship does not offer a unitary picture of this notion. This paper carries out a literature review of the topic and suggests a new systematisation of the theoretical framework surrounding the concept of digital constitutionalism. It is argued that digital constitutionalism is the ideology that adapts the values of contemporary constitutionalism to the digital society. It does not identify the normative responses to the challenges of digital technology, but rather embodies the set of principles and values that informs and guides them. Conversely, the emerging normative responses can be regarded as the components of a process of constitutionalisation of the digital environment. In light of the adopted definitions, the paper ultimately illustrates a new way of mapping the constitutional responses that have emerged to address the challenges of digital technology. They not only include the constitutional tools that we could define as 'classic' in the context of constitutional theory, such as the binding legal texts produced in the state-centric dimension, but, significantly, also new instruments, which are developed in the transnational dimension of private actors.
\end{abstract}

Keywords: constitutionalisation, Internet bills of rights, private actors.

My drawing was not a picture of a hat. It was a picture of a boa constrictor digesting an elephant.

(Saint-Exupéry 1943, 2)

\section{Introduction}

At the very beginning of The Little Prince (Saint-Exupéry 1943), the narrator shows us a picture of what we think is a hat, subsequently revealing that, in fact, the drawing was supposed to be a snake swallowing an elephant. The reader is encouraged to look at things always from a different perspective, and to understand that the reality is never black or white - a hat or an elephant, but constantly changes according to our point of view. It is in this spirit that this paper has adopted a constitutionalist approach in order to read, through a different theoretical lens, a series of current transformations affecting the legal order (cf. Peters 2014).

Such a perspective allows us to notice that contemporary society is experiencing a new constitutional moment, whose main catalyst is the disruptive impact of digital technology (see Mayer-Schönberger and Crowley 2006; Rodotà 2010; cf. Fischer-Lescano 2005; Slaughter and Burke-White 2002). As we will see more in depth in the second section, on the one hand, 
technological advancements have manifestly amplified the possibility for individuals to exercise their fundamental rights. One significant example of this is our unprecedented capability to communicate easily with each other, which was truly unforeseeable some decades ago. On the other hand, digital technology has also created new sources of threats to our fundamental rights. The increasing risks deriving from the processing of our personal data facilitated by the use of digital devices are exemplary. Last, but not least, the rising relevance of digital technology in contemporary society has vested an extraordinary amount of power in non-state actors, such as the big multinational corporations and the transnational organisations which own, commercialise or manage this technology, to the detriment of traditional constitutional actors like nation states.

These changes can be globally interpreted as an alteration of the constitutional equilibrium against which, interestingly, the constitutional system is responding through a series of normative counteractions (see Celeste 2018b). A constitutionalist interpretation of this complex phenomenon can enable future research to explain the reasons underlying these intertwined processes, to evaluate their state of advancement as well as to speculate on the course of their future development (cf. Suzor, Van Geelen, and Myers West 2018; Peters 2014; Viellechner 2012; Karavas 2010; Kadelbach and Kleinlein 2007; Lessig 2006). However, in order to achieve this objective, it is necessary to handle the conceptual machinery of constitutional theory, and, if need be, to reinterpret it.

This paper engages in this intellectual endeavour. The idea of 'digital constitutionalism' seems an appealing concept to shed some light on the current constitutional moment, and in particular to explain why this series of constitutional counteractions are materialising and what their guiding principles are. However, in the existing scholarship, this concept has been used with different and sometimes conflicting meanings, apparently without reaching any agreement on what its scope is and on which normative instruments should implement its values. Due to the lack of a comprehensive picture of these different positions, the third section of this paper will carry out a literature review of the topic.

This paper will argue that the various ways in which the doctrine has conceptualised 'digital constitutionalism' can be eventually reconciled. To this end, the fourth section will illustrate a new systematisation of the theoretical framework surrounding the concept of digital constitutionalism. This notion will be defined as the ideology that adapts the values of contemporary constitutionalism to the digital society. In contrast to what some scholars argue, it will be clarified that digital constitutionalism does not identify the normative responses to the challenges of digital technology, but it is rather the set of principles and values that informs, guides and determines the generation of those responses. Conversely, it will be argued that the latter can be regarded as the components of a process of constitutionalisation of the digital environment.

In light of these definitions, the last section of this paper will outline a new panoramic picture of the constitutional responses which emerged so far to address the challenges of digital technology. In particular, this vision will innovatively combine the constitutional tools analysed by the majority of scholars, which we could define as 'classic' in the context of constitutional theory, such as the binding legal texts produced in the state-centric dimension, with new instruments, which are developed in the transnational dimension by private actors.

\section{A constitutional moment}

The incessant development of digital technology and its disruptive impact on contemporary society are generating a new constitutional moment. A constitutional moment does not mean a 
constitutional upheaval (cf. Mayer-Schönberger and Crowley 2006; Böckenförde 2017; Castorina 2015; see also Rodotà 2010; Fischer-Lescano 2005; Slaughter and Burke-White 2002). We are not facing a Copernican change of paradigm altering the core principles which characterise our constitutional identity (see Böckenförde 2017), a transition from democracy to technocracy (Castorina 2015). However, there is little doubt that digital technology is affecting existing rights, leading to the recognition of new rights or new facets of existing rights (cf. Castorina 2015). Over the past few decades - one could say - digital technology has affected the equilibrium of the constitutional ecosystem. Consequently, a series of normative counteractions have emerged to face the challenges of digital technology and restore a condition of relative equilibrium. The next two paragraphs will schematise these two logically distinct, but de facto intertwined processes. The last paragraph of this section will illustrate to what extent 'digital constitutionalism' is an appealing concept to explain this phenomenon.

\subsection{The alteration of the constitutional equilibrium}

This paper defines constitutional equilibrium as the ideal condition produced by the application of the norms of constitutional law in a given legal order (see Celeste 2018b). Such a condition essentially involves two aspects, which reflect the basic functions of constitutional law: 1) the protection of fundamental rights, and 2) the balancing of powers (Peters 2006).

This section does not focus on a specific legal order, but rather shows, from a general perspective, that the constitutional ecosystem is not immune to digital technology (see Sartor 2017). This paper argues that the advent of digital technology generates the following alterations in the constitutional ecosystem:

a) It amplifies the possibilities for individuals to exercise their fundamental rights. Digital technology expands the possibility to transmit information. From a constitutional point of view, this circumstance implies that all fundamental rights based on the exchange of information, such as freedom of expression, religious freedom, freedom of assembly, freedom to conduct a business are enhanced.

b) Digital technology amplifies the risk of threats to fundamental rights. The same increased possibility to exchange information enabling the exercise of fundamental rights can also become a source of threats. Defamation, hate speech, cyberbullying, child pornography are some examples of how freedom of expression can be abused through digital instruments. Moreover, digital technology not only enhances the possibility of transmitting information, but it also allows: 1) blocking or limiting such a transmission, 2) monitoring the content of the transmitted information, and 3 ) registering other information related to the individuals involved in the transmission. In the first case, a limitation of the transmission of information could violate all the rights which are based on that transmission, such as freedom of expression, information, association, etc. In the second case, the transmitted information could be confidential and/or could include personal data; therefore, an unlawful access to such contents could violate all the rights aiming to protect the personal sphere of the individual, such as the right to privacy, right to respect of private life, secrecy of correspondence, right to data protection, as differently articulated in the various legal systems. In the third case, other information concerning the transmission of information could represent personal data, and, therefore, an illegitimate use of such data could infringe the rights aiming to ensure their protection.

c) Digital technology affects the balancing of powers in the constitutional ecosystem. Considering the power in a general sense, as the ability of a constitutional actor to direct the behaviour of another actor, it is possible to observe that private corporations producing, selling and managing digital technology products and services worldwide are emerging in the 
constitutional scenario as a new dominant actor beside nation-states (see Teubner 2004, 2012; Rodotà 2010). Historically, modern constitutional law aimed to provide mechanisms of power balancing (see McIlwain 2007). The state was the main dominant actor within the polity and, consequently, existing constitutional instruments established ways to limit its power in order to guarantee individual fundamental rights. As a consequence, the legal obligation to respect individual rights only binds the state. Private entities are not directly subject to these standards. It is a duty of the state to ensure that such entities respect these rights (Jørgensen and Pedersen 2017). However, in the digital society, tech corporations, too, detain a form of power. They act as 'online gatekeepers' (Laidlaw 2008, see 2015). They have the power to regulate the access and use of individuals to digital technology instruments and, consequently, they can affect the way in which individuals exercise their rights through these instruments. Certainly, violations of fundamental rights perpetrated by private actors are not a novelty generated by the advent of digital technology (see, ex multis, Clapham 2006). Nevertheless, in the context of the digital society, their likelihood increases. This phenomenon can be explained by the massive diffusion of digital technology instruments among individuals combined with the dominant role that private corporations play in the digital environment. Tech companies control a substantial component of the everyday life of an unprecedented number of people. The possibility that these non-state actors interfere with our fundamental rights becomes more likely and intense, and, at the same time, this circumstance is not adequately addressed by the existing mechanisms of power balancing, which rather focus on the relationship between individuals and nation-states (cf. Ridola 2018).

\subsection{The emergence of normative counteractions}

The alterations of the relative equilibrium of the constitutional ecosystem have in turn generated a series of normative counteractions. As we will more concretely see in the last section of this paper, these counteractions consist in the integration or in the amendment of the existing normative framework and aim to restore a condition of relative equilibrium in the constitutional ecosystem. This twofold phenomenon combining alterations and counteractions is not an absolute novelty in legal theory. In similar terms, Bobbio described the emergence and consolidation of human rights (1996). He believed that human rights historically arose from the need to safeguard freedoms against existing powers. For example, he explained that religious freedom first emerged in response to the religious wars, civil liberties to absolute monarchies, etc. This gradual emergence of rights due to different socio-historical factors is also evident in the common way of distinguishing 'generations' of rights. According to this theory, for example, the state of oppression of ordinary people generated by the abuses of privileged social classes, first, and of the state, later, would have led to the progressive affirmation, from the end of the 18th century, of the 'first generation' of human rights, mainly including civil and political rights (see Bobbio 1996; cf. Donnelly and Whelan 2018). Therefore, this view, too, provides plausibility for the present theoretical reconstruction, which espouses the idea that the ongoing elaboration of constitutional counteractions is seeking to address contemporary societal challenges generated by the development of digital technology.

With no pretention to provide an exhaustive directory, it is useful to categorise these normative counteractions according to the kind of alteration they aim to address. Following the schematisation outlined in the previous paragraph, it is possible to detect three categories of counteractions:

a) Norms aiming to recognise the increased possibility of exercising an existing fundamental right. Over the past few years, digital technology has been an extraordinary enabler of fundamental rights. The use of digital technology instruments has become an integral part of 
the architecture of contemporary society, so much so that sometimes it may be deemed as a necessary precondition to exercising a series of rights, such as, for example, the right to access information or the right to work (see Celeste 2018a; cf. Karppi 2018). Therefore, as an example of this first category of norms, one can mention those recognising a right to Internet access as a necessary condition to exercise a whole series of existing rights, ranging from freedom of expression to freedom to conduct a business. ${ }^{1}$

b) Norms aiming to limit the increase of fundamental rights violations. An apparent example of the emergence of these norms is represented by the development of data protection law. From the 1960s, the advent of computing technology allowed, for the first time, the creation of big databases and increased the possibility to easily transfer the data stored within them. This new development manifested a series of potential risks for the security of the stored data, especially if they represented information related to individuals. This circumstance led to the emergence of what we now call data protection law (Blume 2010; see Council of Europe 1981).

c) Norms aiming to restore a balance among existing powers. For example, those requiring public institutions to publish selected information on their website, or those establishing a right to access documents held by public institutions through digital technology instruments. ${ }^{2}$ In fact, both these kinds of norms aim to introduce new forms of citizens' control on the power of public institutions. This circumstance does not fully compensate the existing asymmetry of power between citizens and state. However, in this way, the conduct of a dominant actor, such as the state, is put under the scrutiny of the citizens, ultimately allowing them to react against potential abuse of state's power. These newly emerging norms represent a specific application of the citizens' right to information with regard to the state. This right emerged well before the advent of digital technology (see Mustonen 2006; Foerstel 1999); nevertheless, it is possible to contend that the advent of digital technology undoubtedly provided a boost for the implementation of the principle of freedom of information. Indeed, these new technologies have offered, for the first time, the technical possibility to instantaneously give access to an unprecedented amount of governmental information at lower costs. With the advent of digital technology the concept of 'democracy in public' proposed by Bobbio has eventually found the technical instruments to be substantiated (Bobbio 1991; see also Rosanvallon 2006; Costanzo 2012).

\subsection{The role of digital constitutionalism}

The emergence of these counteractions generates two main questions. Firstly, why these normative responses should materialise and, secondly, what their guiding principles are. Analysing this phenomenon through a constitutionalist lens allows us to hypothesise an answer to these issues.

In relation to the first question, one could argue that contemporary constitutionalism has always sought to ensure the protection of fundamental rights and the balancing of power in a given legal order through constitutional law (see Waldron 2010; Sajó 1999; cf. Weiler and Wind 2003;

\footnotetext{
1 See, e.g. Conseil constitutionnel (France), decision $\mathrm{n}^{\circ}$ 2009-580 DC du 10 juin 2009, para. 12, http:/www.conseil-constitutionnel.fr/conseil-constitutionnel/root/bank/download/cc-2009580dc.pdf; $\quad$ Sala Constitucional de la Corte Suprema de Justicia (Costa Rica), sentencia n ${ }^{\circ} 12790$ de 30 de Julio de 2010 , https://www.poder-judicial.go.cr/salaconstitucional/index.php/servicios-publicos/759-10-012790; $\quad$ ECtHR, Cengiz and Others v. Turkey [2015] (Applications nos. 48226/10 and 14027/11), para. 49; Law no. 12.965/2014 (Brazil), so-called 'Marco Civil da Internet', Article 4 and 7 , https://www.publicknowledge.org/assets/uploads/documents/APPROVED-MARCO-CIVIL-MAY-2014.pdf.

${ }^{2}$ See, e.g. Article L311-1 of the Code des relations entre le public et l'administration, as modified by Article 3 of the Loi $\mathrm{n}^{\circ} 2016-1321$ du 7 octobre 2016 pour une République numérique (France); Article 2 of the Legislative Decree no. 33/2013 (Italy); Article 6, 10, 11, and 12 of Regulation (EC) 1049/2011 (EU).
} 
see Milewicz 2009; Wiener 2003). A direct corollary of this principle would be the imperative which requires that an alteration of the constitutional ecosystem should necessarily be followed by an attempt to restore a state of equilibrium, in a similar way to Newton's Third Law of Motion (see Celeste 2018b). Concerning the second question, one could contend that it is again contemporary constitutionalism, intended as an ideology, which provides the guiding ideals, values and principles to restore a state of constitutional equilibrium (cf. Kadelbach and Kleinlein 2007; Suzor, Van Geelen, and Myers West 2018).

Interestingly, from this perspective, it is conceptually appealing to single out the notion of 'digital constitutionalism'. This would allow us to identify the specific strand of contemporary constitutionalism that is translating and adapting existing constitutional values and principles to the peculiarities of the contemporary digital society. In this way, such a denomination would recognise the role that digital technology has recently played as the main catalyst of change in the constitutional environment.

In conclusion, in order to provide a tentative answer to our questions, one could hypothesise that digital constitutionalism, intended as a strand of contemporary constitutionalism, imposes the necessity to generate normative counteractions to the alterations of the constitutional equilibrium that are produced by the advent of digital technology and, at the same time, provides the ideals, values and principles that guide such counteractions.

\section{Doctrinal divergence}

Digital constitutionalism is not a new concept. Thanks to its vague and evocative connotation, the last twenty years of scholarship has employed it in different contexts and with different meanings. Recently, this descriptor has come back in vogue to denote the emergence of the idea of charters of rights for the Internet. However, the core aspects underlying this notion have appeared in the reflections of scholars since the beginning of the 2000s.

Considering the lack of a comprehensive survey of the existing literature on the topic, this section will reconstruct the main developments of the concept of digital constitutionalism in a chronological order.

\subsection{The constitutional role of private law: Fitzgerald}

Fitzgerald recognised that, in the information society, the exercise of power is shared between public and private actors (Fitzgerald 1999, 2000). Therefore, he argued that the concept of constitutionalism, which he intended as the mediation or definition of power relations, does involve both public and private actors.

According to Fitzgerald, the nature of information society, which is international, intangible, non-territorial, and decentralised, requires a mixed governance structure combining private sector's self-regulation and public institutions' oversight. On the one hand, private actors exercise their power by regulating the code of software. On the other hand, public actors maintain an important role at governance level because they can still exercise a coercive power.

'Informational constitutionalism' or 'informational law' is the descriptor adopted by Fitzgerald in order to denote the law of the state (in particular: intellectual property law, contract law, competition law, and privacy law), which should be called to delimit private actors' selfregulation (Fitzgerald 1999, 2000; cf. Amstutz, Abegg, and Karavas 2007).

Fitzgerald's normative theorisation of governance mechanisms in the information society sees states' private law playing the central 'constitutional' role of limiting private actors' self- 
regulation. However, from a general perspective, one could point out two main issues that affect in practice the operability of states' private law in carrying out this task. Firstly, sometimes it is not straightforward to subject private actors to one state's jurisdiction (see, e.g., Google Spain $\mathrm{v}$ APED 2014). Secondly, being the activity of private actors in the information society transnational, there could be collisions with the law of other states (cf. Teubner and FischerLescano 2004).

\subsection{State's constitutional law and private actors: Berman}

Following Lessig (1999, see also 2006), Berman considered private actors' ability to define cyberspace's code as a powerful regulatory instrument (2000; cf. Fitzgerald 2000). In his paper, he analysed whether those actors should therefore be subject to US constitutional law. In the US, the state action doctrine limits constitutional adjudication to the conduct of public actors (cf. Karavas and Teubner 2005; Engle 2009).

Berman proposed a 'constitutive constitutionalism' as an alternative solution to bypass the state action doctrine and, eventually, to subject private actors to US constitutional law. According to Berman, constitutional adjudication should be extended to private actors instead of using ordinary law. In this way, courts could use the constitution as a benchmark for developing fundamental values, solving politically demanding questions, and encouraging people to engage in these issues (Berman 2000).

In contrast to Fitzgerald, who recognised the role of private law in limiting the power of private actors, Berman explicitly rejected the idea that, what he calls, 'ordinary law' could perform such a constitutionalising function. Constitutional law would be naturally inclined to establish general principles, while the aim of ordinary legislation would be limited to the regulation of problems of daily life (cf. Kay 1993). However, from this exclusion, one could propose a significant criticism to Berman's position. As recognised by Fitzgerald, indeed, ordinary law could reflect or be permeated by constitutional values, and therefore one cannot exclude that it does not act as an important constitutional instrument in the sphere of private actors.

\subsection{Constitutional values, private law and self-regulation: Suzor}

Drawing from Fitzgerald's theorisation, Suzor recognised the role of private actors' power in the regulation of virtual communities (Suzor 2010). Referring both to Fitzgerald and Berman, he affirmed that a constitutional perspective is useful in order to understand what the appropriate limits to the power of commercial private actors should be. For this reason, he decided to employ the descriptor 'digital constitutionalism' to denote the project which seeks to articulate a set of limits on private power, with particular attention to the context of virtual communities, ${ }^{3}$ the topic in which he focused his doctoral thesis. The concept that was previously denominated 'informational constitutionalism' by Fitzgerald and 'constitutive constitutionalism' by Berman eventually acquires the name of 'digital constitutionalism', a denomination that would be maintained by subsequent scholars.

In line with Fitzgerald, Suzor considered the contractual framework of virtual communities as their law, and, consequently, the limitations imposed on that framework by contract law as their constitutional principles. Virtual communities' self-regulation is considered as legitimate, even if it is unilaterally established, because users provide their consent to it. However, despite the presence of valid consent from the users, such a law could infringe some external values

\footnotetext{
${ }^{3}$ Suzor adopts a broad definition of virtual communities encompassing the whole spectrum of online social platforms, from social media to online forums and chat rooms (see Suzor 2010, 27).
} 
imposed by the state. For this reason, the contractual framework of virtual communities is subject to the limitations imposed by contract law.

In contrast to Berman, Suzor does not contend that the ultimate control of private power should be exercised by constitutional law. However, differently from Fitzgerald, Suzor argued that constitutional law plays a twofold role in the limitation of private power. Firstly, it can be used to determine the extent to which private actors' self-regulation is complying with the values established by the state. Secondly, it has the duty to inform and lead the development of contract law. In this way, constitutional principles, such as the rule of law, could be transferred into the regulation of virtual communities via contract law. ${ }^{4}$

Similarly to Fitzgerald, Suzor theorised the governance model of virtual communities as a mixture of public and private power. However, he underlined that such a model does not reflect a precise hierarchy between private self-regulation and state law, but he considered these two sources as melding together in a 'mesh' of public and private governance schemes. ${ }^{5}$ According to Suzor, state law is losing its centrality in contexts, such as virtual communities, dominated by the law of private actors. Conversely, private self-regulation is increasingly central, considering the rising relevance of virtual communities in the life of individuals. Nevertheless, Suzor argued that attempts to achieve a democratisation or a model of joint governance in virtual communities have essentially failed, ${ }^{6}$ and that, for this reason, the limiting role that state law should play remains crucial.

By recognising the constitutionalising role played by private law, and, at the same time, the guiding and informative function of constitutional law, Suzor somehow reconciled Fitzgerald's and Berman's positions. However, the criticism already reported in relation to Fitzgerald could still be advanced. By granting a role to state legislation, be it of constitutional or ordinary value, one unavoidably attempts to subject the digital environment to states' jurisdiction, according to criteria developed for the physical world, which do not adequately fit the transnational nature of online services.

\subsection{Constitutionalisation without the state: Karavas}

Karavas shares with Suzor the primary scope of his analysis: virtual worlds (Karavas 2010). He examined as a case study the decision of a German court concerning the ban of a user from a chat forum. ${ }^{7}$ The judges of the Landgericht Bonn ordered the reintegration of the user in the forum because the owner of the platform had not previously established certain rules on the use of the chat. The court, however, did not rely on any constitutionalist interpretation. Denying access to a chat forum on the basis of arbitrary principles could have been read in terms of restriction of the individual right to freedom of expression. One could have imagined a reference to the values of rule of law and transparency or the typically German direct/indirect application of fundamental rights to private actors, the so-called Drittwirkung (Karavas 2010). Instead, the court simply invoked the general principle of good faith established by the German civil code.

\footnotetext{
${ }^{4}$ Suzor refers to Dicey's doctrine on the role of private law in countries, like the United Kingdom, with an unwritten constitution: "This project follows somewhat from A V Dicey's argument that in the absence of a substantive written constitution, rule of law principles in the United Kingdom were protected by the evolution of private law doctrines that secured the substantive rights of citizens." $(2010,53)$.

${ }^{5}$ Suzor explicitly refers to the model developed by Jeanne P. Mifsud Bonnici (2008).

${ }^{6}$ Suzor refers to Balkin (2004). In particular, he mentions as an example of successful joint governance model Wikipedia, while, as an example of failure, Facebook's attempt to involve its users in the process of revision of its terms of use.

${ }^{7}$ Landgericht Bonn, Urteil vom 16. November 1999, 10 O 457/99, https://openjur.de/u/150000.html.
} 
Karavas did not interpret this case as a traditional private law dispute, but considered it as an evidence of a specific type of constitutionalisation that the German judges intended to pursue. In essence, he argued that, in this case, the German judges were implicitly recognising the failure of a constitutionalisation of cyberspace led by the state, and were therefore supporting with a sort of "maieutic" attitude (Karavas 2010, 168) - an "incremental" and "bottom-up" constitutionalisation process promoted by different societal sub-sectors without the state (2010, 167-68). In other words, Karavas claimed that state politics is no longer able to fully regulate the complexity of a fragmented and plural society, and consequently espoused the thesis first advanced by Teubner of a long process of emergence of 'civil constitutions' (Teubner 2004). It is in this context that Karavas used the heading "digital constitutionalism" $(2010,163)$. He did not explicitly define this notion, but one can understand that he was referring to this "revolutionary plan" for the constitutionalisation of virtual worlds introduced by the German court (Karavas 2010, 163).

In conclusion, Karavas offers us an intermediate position between an idea of constitutionalism anchored to the state, as we have previously seen in Fitzgerald and Berman, and a vision where the constitutionalisation process is autonomously led by societal sectors, as the next paragraph will illustrate. Interestingly, Suzor and Karavas seem to be the two sides of the same coin: each one recognised the possibility of self-regulation of private actors, but the first is convinced that state values should guide this development, while the second supports the idea that societal subsectors are now able to lead their own constitutionalisation process.

\subsection{The Internet bills of rights: Gill, Redeker and Gasser}

In 2015, Gill, Redeker and Gasser published a working paper on 'digital constitutionalism' (2015). They proposed to use this descriptor as an umbrella term to connect a set of documents seeking to establish a bill of rights for the Internet. They argued that these texts, which have emerged in the last twenty-five years, are very different, but that they could be regarded as a part of a broader 'pre' or 'proto-constitutional discourse', as "intellectual building blocks for the constitutional material of the digital sphere" whose ultimate aim is to define a comprehensive set of rights, principles, and governance norms for the Internet (Gill, Redeker, and Gasser 2015, 3). Moreover, such a constitutional discourse is not seen as static; the working paper highlights a progressive trend towards a crystallisation of principles into binding legal texts (cf. Musiani, Pavan, and Padovani 2009).

Nevertheless, according to Gill, Redeker and Gasser, these Internet bills of rights are not constitutions in the classic sense, intended as "mechanisms which delimit the boundaries of a state's power over its citizens" $(2015,22)$. Indeed, these texts lack a quintessential characteristic of constitutions: they do not have any foundational or primary position in the hierarchy of legal sources. However, according to the authors of the working paper, they can be associated with constitutions because they share the "core substantive aspects" of constitutionalism, such as its values, problems and principles as well as its main functions of limiting state powers and empowering institutions within the society $(2015,23)$.

Gill, Redeker and Gasser argued that their conception of digital constitutionalism is not as narrow as that of Suzor, who referred to the limitation of power only within the context of virtual communities. In reality, rather than broader, their interpretation appears to be different. For them digital constitutionalism aims at the limitation of public power, while for Suzor at that of private power (see Yilma 2017). Moreover, Gill, Redeker and Gasser identified such a limitative function in the documents of Internet bill of rights, while Suzor in the private law of the state. 
The main merit of the working paper authored by Gill, Redeker and Gasser is to have carried out the first systematic and comprehensive empirical analysis on the emergence of the texts of Internet bills of rights, stimulating a new series of research on this topic (see Yilma 2017; Celeste 2018b). However, taking into account the different positions adopted by Fitzgerald, Berman and Suzor, two points can be made about the conception of digital constitutionalism presented in their working paper.

Firstly, the restriction of the concept of digital constitutionalism to the limitation of public power - therefore excluding a role in limiting private power - does not seem to be justified (see Graber and Teubner 1998). Secondly, one could question why the concept of digital constitutionalism should be restricted to the emergence of the Internet bills of rights, and not to extend to the role performed by private law and constitutional law in limiting private power, as in Fitzgerald, Berman and Suzor.

In 2018, Redeker, Gill and Gasser published a re-elaboration of their work of 2015 in a special issue of the International Communication Gazette focusing on the topic of digital constitutionalism (2018). Their paper includes two main novelties.

Firstly, they departed from the conception of digital constitutionalism only referring to the limitation of public power. They recognised that "[i]n today's political economy of the Internet, states and private corporations alike can either limit or contribute to the realization of perceived digital rights" (Redeker, Gill, and Gasser 2018, 304), and that, consequently, digital constitutionalism could refer to the limitation of both public and private power.

Secondly, in line with Karavas (2010), they embraced Teubner's theory of societal constitutionalism (Teubner 2004). Teubner argues that constitutional norms can also be produced through a bottom-up process. Autonomous social sectors elaborate norms, which are progressively institutionalised at legal level, through a mutual influence between state institutions and social context. Redeker, Gill and Gasser contended that the emergence of documents of Internet bills of rights could be interpreted as the first phase of the process described by Teubner, and, therefore, as the juridification or institutionalisation at social level of new constitutional principles (see Graber 2016). Moreover, they identified a progressive trend towards codification of these texts into binding legal documents, and they claimed that this circumstance could be read as an evidence of the process of institutionalisation of the Internet bills of rights. ${ }^{8}$

Undoubtedly, the expanded conception of digital constitutionalism encompassing both the limitation of public and private power reinforces Redeker, Gill and Gasser's analysis, and eliminates one of the main criticisms advanced against their paper of 2015. However, the second remark presented above still persists. The concept of digital constitutionalism seems to be still uniquely associated to the emergence of the Internet bills of rights, somehow implicitly excluding that it could be referred to the limitation of private power performed by private law, constitutional law, and by the principles developed by transnational organisations like ICANN. ${ }^{9}$

Furthermore, it is possible to criticise the reduction of the whole concept of 'juridification' to its specific meaning of institutionalisation of a document within the hierarchy of legal sources of a specific legal order. Redeker, Gill and Gasser affirm that the level of development of the documents of Internet bill of rights does not overtake the first or the second phase of the process

\footnotetext{
${ }^{8}$ They mention as an example the adoption in Brazil of the so-called Marco Civil da Internet, Law no. 12.965, 23 April 2014 (see Medeiros and Bygrave 2015).

${ }^{9}$ Redeker, Gill and Gasser explicitly exclude to deal with these principles because their analysis "focus[es] on documents that aim at transforming Internet governance per se - even if limited by some documents' spatial focus, rather than a document defining the rules governing one particular organization, however great the importance of the organization for the governance of the Internet" $(2018,307)$.
} 
of societal constitutionalisation described by Teubner (see Graber 2016). This means that these texts either remain "embodiment of normative stances of civil society and other groups" or can become legally binding, nevertheless without any "preeminent status" (Redeker, Gill, and Gasser 2018, 304-5). However, the concept of juridification not only encompasses the institutionalisation of a whole document, but also the institutionalisation of the norms and principles enshrined in such a document. In other words, one could argue that it is necessary also to look at whether and to what extent the norms and principles included in the Internet bills of rights have been institutionalised, and not only at whether the whole document has acquired a binding legal status. In fact, the interaction between national and transnational, institutional and societal dimensions could be metaphorically described as an exchange of fluids between porous and permeable materials: the components of the material itself do not move, but it is the fluid to be alternatively absorbed by one and the other material (Teubner 1993; Graber 2016; Simoncini 2016; see De Minico 2015). In other words, one could theoretically imagine that a document of Internet bill of rights does not become legally binding, but conversely its norms and principles are recognised in a higher source of the legal order (see Teubner 2004).

Finally, always in relation to the application of the Teubnerian theory of societal constitutionalism, one could question the correspondence of the documents of Internet bills of rights with the first phase of societal constitutionalisation described by Teubner. In particular, one could claim that such a first phase presupposes that an agreement on a set of norms has been reached at societal level. However, it would be appropriate to investigate to what extent and in which contexts specific norms have assumed sufficiently determined contours at social level (cf. Graber 2016). In fact, if one observes the number of Internet bills of rights which have emerged so far, one could argue that an agreement on the content of specific norms has not been reached yet. Therefore, it is the opinion of the author that the process of emergence of documents of Internet bill of rights has not yet produced specific norms shared at social level, or, in other words, that the first phase of the process of constitutionalisation described by Teubner is still ongoing.

\section{A new systematic theorisation}

The existing literature does not offer a unitary picture of the concept of digital constitutionalism. In particular, there is no consensus on two fundamental characteristics of this notion. Firstly, on the scope of digital constitutionalism: it is not clear whether it aims to limit the private power or also the public power. Secondly, there is no agreement on the instrument which should implement the values of digital constitutionalism. Interestingly, we have depicted an image of a progressive twilight of the role of the state and a parallel increase of the power of societal sectors. Fitzgerald entrusts a constitutionalising role to private law, Berman to constitutional law, Suzor to a private law informed by the principles of constitutional law, Karavas to norms produced by private actors, and finally Redeker, Gill and Gasser to the documents of Internet bill of rights.

On the one hand, the existing literature does not show doubts in relation to the notions of 'constitution' and 'constitutional law'. In fact, all the analysed authors refer to their traditional meanings proper to the state dimension (see also Padovani and Santaniello 2018). On the other hand, the notions of 'constitutionalism' and 'constitutionalisation' appear to be surrounded by a certain nebulosity, especially because they are generally dis-anchored from the traditional context of the state and projected in a transnational dimension.

This paper builds on the existing literature in order to reconcile these apparently divergent positions and to define more clearly the concepts of digital constitutionalism and constitutionalisation of the digital environment. To this end, the diagram below has been created 
to better visualise the new proposed theoretical systematisation and to provide a schematisation of the argumentative line that the next sections of this paper will follow.

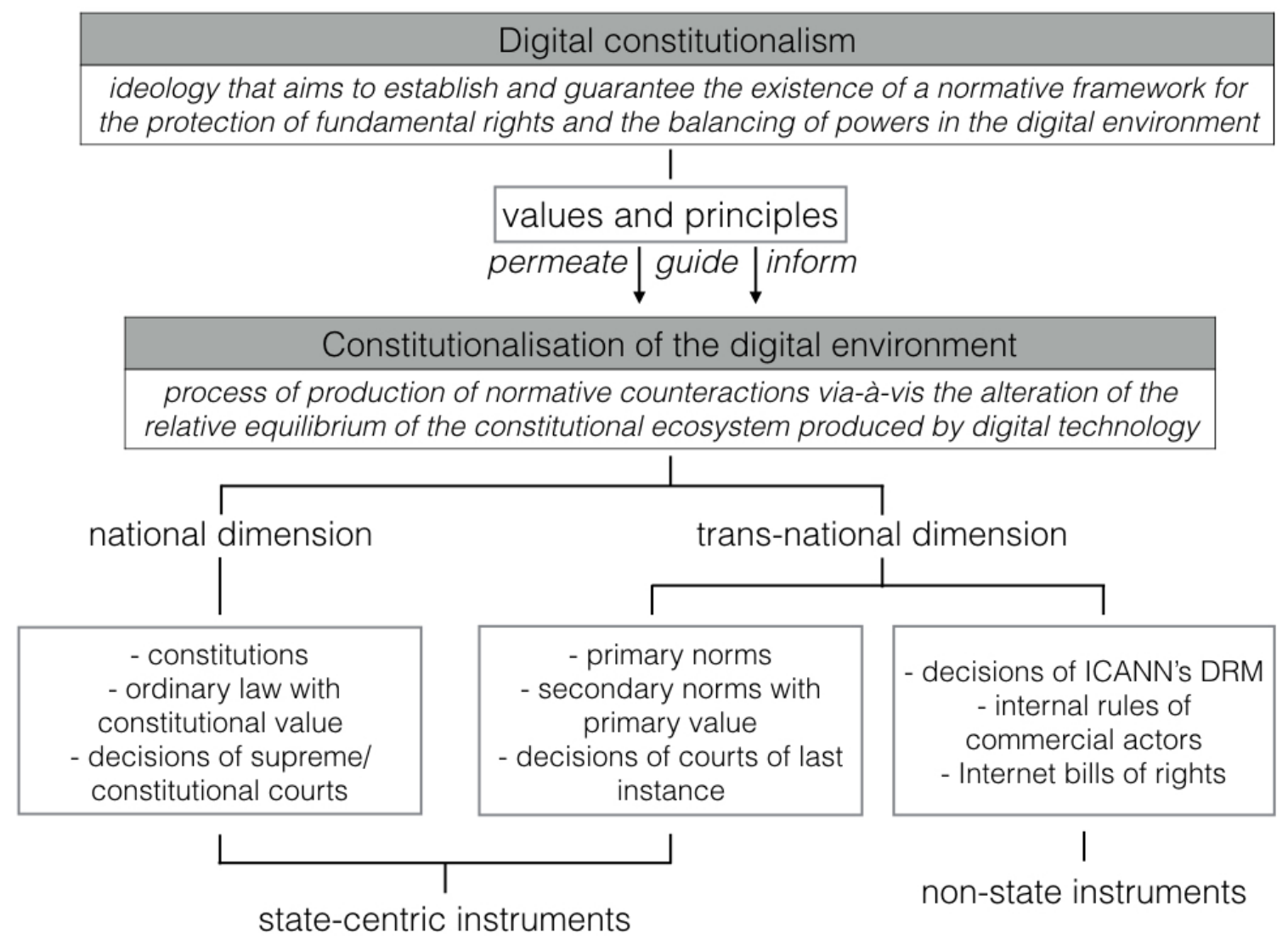

\subsection{Digital constitutionalism as an ideology}

Constitutionalism is not a univocal and immutable concept, but has historically evolved, as the different denominations of 'liberal' or 'democratic' constitutionalism demonstrate (Dowdle and Wilkinson 2016; Costanzo 2012). Its contemporary notion rotates around the idea of limiting the power of government, and includes, among its foundational values, democracy, the protection of human rights and the rule of law (see Sajó 1999; Grimm 2010; Waldron 2010). Digital constitutionalism is a new strand of contemporary constitutionalism. However, it does denote a new stage of evolution of constitutionalism, which marks a revolutionary change and implies the transition to new values and ideals, like it happened when constitutionalism eventually became 'democratic'. It is rather one of its recent directions. In this expression, 'digital' does not directly qualify the term 'constitutionalism', but it is rather an adverbial conveying the idea that one is referring to the constitutionalism related to the digital environment.

Digital constitutionalism consequently shares the foundational values and the overall aims of contemporary constitutionalism, but focuses on the specific context affected by the advent of digital technology. Also digital constitutionalism is an 'ism' (cf. Peters 2014; Ridola 2018; Blokker 2011), and therefore one could define it as the ideology which aims to establish and to ensure the existence of a normative framework for the protection of fundamental rights and the balancing of powers in the digital environment (cf. Costanzo 2012). 
The term 'ideology' is often used in a pejorative sense, following Marx's concept of ideology as 'false consciousness', i.e. as "a set of beliefs with which people deceive themselves", or like in politics, as a non-practical attitude (Cranston 2014). In this paper, this descriptor is used in a neutral way, as a structured set of values and ideals (cf. Viellechner 2012). The advantage of thinking of digital constitutionalism as an ideology, and, therefore, as a purely theoretical concept, lies in the possibility to distinguish it from its implementation, its translation into reality, as we will see in section $4.3 .^{10}$

\subsection{The scope of digital constitutionalism}

The literature review presented in this paper showed that there is no consensus among the analysed scholars on the scope of digital constitutionalism. Fitzgerald, Berman, Suzor and Karavas intended constitutionalism as the limitation of private power. ${ }^{11}$ Redeker, Gill and Gasser, in the second version of their paper, affirmed that "[e]fforts toward digital constitutionalism may aim to limit the power of both public authorities and private corporations" (2018, 304).

As recognised by Redeker, Gill and Gasser (2018), this paper submits that there is no reason to restrict the concept of digital constitutionalism to the limitation of either public or private power (see Pernice 2014; Costanzo 2012). Digital constitutionalism, indeed, is a concept which refers to a specific context, the digital environment, where private actors emerge beside nation states as new dominant actors, at the same time, ultimate guarantors and potential infringers of fundamental rights. Such a peculiarity of the digital environment requires to dis-anchor the concept of constitutionalism from the state dimension in order to fully appreciate the emergence of the powers of private actors (cf. Preuss 2010; Loughlin 2010; Walker 2003; Viellechner 2012; Wiener et al. 2012).

This interpretation is the result of a process of generalisation and subsequent re-specification of the concept of constitutionalism in relation to the digital environment (Teubner 2004). The intellectual exercise of generalisation allows us to abstract the notion of constitutionalism from the specific context in which it emerged - the state dimension - by identifying its quintessential functions, which, according to this paper, are the protection of fundamental rights and the balancing of existing powers (Peters 2006; see also Viellechner 2012; Wiener et al. 2012). Subsequently, the exercise of re-specification allows us to re-contextualise these two functions in the digital environment. In this way, it is apparent that, in a context where both public and private actors can affect the protection of fundamental rights, digital constitutionalism does involve the limitation of the power of both these categories of actors.

A similar conception of digital constitutionalism frees itself from the ties anchoring it to the state dimension, in which the broader notion of constitutionalism emerged. As we will see in the last section, this interpretation of digital constitutionalism also implies to reconsider the kinds of normative counteractions that emerge in order to implement its values and principles.

\footnotetext{
${ }^{10}$ For example, the concept of digital constitutionalism does not correspond, as some scholars seem to suggest, to the documents of Internet bill of rights (see Padovani and Santaniello 2018; Yilma 2017). As correctly specified by Redeker, Gill and Gasser, digital constitutionalism is "a common term to connect a constellation of initiatives" $(2018,302)$. Therefore, it connects, but it is not the constellation of initiatives analysed by Redeker, Gill and Gasser. Digital constitutionalism is the ideology which permeates, guides, informs the emergence of the Internet bills of rights - but not only of these documents, as we will see in section 5 .

${ }^{11}$ Admittedly, their papers focused on private actors. Therefore, one could argue that these authors do not exclude that the concept of digital constitutionalism may be referred to the limitation of public actors. Evidence of that is the fact that Fitzgerald, Berman, Suzor and Karavas are well conscious that they are adapting the concept of constitutionalism, traditionally associated with the context of public power, to the limitation of private power.
} 
It will be possible to identify not only traditional normative answers belonging to the hierarchy of sources of the state-centric dimension, but also different instruments emerging in the transnational context.

\subsection{Constitutionalism v constitutionalisation}

This paper adopts the expression 'constitutionalisation of the digital environment' to identify the process of production of norms aiming to ensure the protection of fundamental rights and the balancing of powers within that context (see Jamart 2014; Pernice 2016; Mayer-Schönberger and Crowley 2006; Karavas 2010; Teubner 2012; Celeste 2018b; cf. Kittichaisaree 2017; Loughlin 2010; Viellechner 2012; Peters 2014; Kadelbach and Kleinlein 2007). In particular, this paper submits that, in this specific historical moment, such a process aims to produce a series of normative counteractions to address the alterations of the constitutional ecosystem generated by the advent of digital technology. In light of this definition, it is important to make a series of clarifications.

Firstly, it is necessary to understand the relationship between constitutionalisation of the digital environment and digital constitutionalism. The latter represents the set of values and ideals that permeate, inform and guide the process of constitutionalisation of the digital environment. Digital constitutionalism provides the imperative at the basis of the process of constitutionalisation as one of its corollary, imposing, in this way, the production of normative counteractions that address the challenges of digital technology.

Secondly, it is important to emphasise that constitutionalisation is a process composed of different stages. This term is not exclusively used to refer to the final stage(s) of such a process in which norms are institutionalised or constitutionalised. It is worth highlighting this aspect because, in contrast to part of the existing scholarship, ${ }^{12}$ this paper argues that the mere elaboration of constitutional principles at societal level can mark the presence of a process of constitutionalisation in the digital environment, even if norms are not yet institutionalised or positivised in the hierarchy of legal sources (see Karavas 2010; cf. Bobbio 1996).

Lastly, the process of constitutionalisation of the digital environment is not unitary (cf. Peters 2014). Even if from a conceptual point of view it is possible to identify common foundational values, motivations and aims, the process of constitutionalisation does not adopt a single modality, but it is translated into different normative answers, which sometimes are stratified, or even overlapping (see Viellechner 2012; cf. Rubenfeld 2004). The next section will illustrate a mapping of these different kinds of modalities.

\section{Mapping constitutional responses}

The bottom of the diagram presented above visualises the different categories of constitutional responses that could be regarded as parts of the process of constitutionalisation of the digital environment. It is important to stress that this paper does not aim to provide an exhaustive directory of all the constitutional responses which have emerged so far. Rather, its objective is to show that the adopted definition of the process of constitutionalisation of the digital environment can encompass all the constitutional instruments analysed by the existing

\footnotetext{
${ }^{12}$ Padovani and Santaniello (2018), for instance, exclude that the emergence of documents of Internet bills of rights could be the evidence of an ongoing process of constitutionalisation. However, they argue that the appearance of these texts is a necessary - but not sufficient - precondition for a process of constitutionalisation of the Internet. Conversely, it is submitted that a process of constitutionalisation starts from the theorisation of constitutional principles, and cannot be reduced to the final institutionalisation and positivisation of the latter.
} 
scholarship, and, in this way, reconcile their positions. To this purpose, rather than focusing on the substantive content of these normative counteractions, this section will look at their source and at the normative instruments they adopt. A series of examples will be provided for each category.

\subsection{National dimension}

Firstly, it is possible to identify a category of normative counteractions developed at national level, which we could define as 'classic' in the constitutional context. They integrate or modify the legal framework through legally binding texts belonging to the hierarchy of legal sources, such as constitutions and other texts with primary value, ${ }^{13}$ ordinary law with constitutional value $^{14}$ as well as decisions of supreme/constitutional courts ${ }^{15}$. In this category, we find the instruments taken into consideration by Fitzgerald (ordinary law), Berman (constitution, decisions of constitutional courts), and Suzor (constitution, ordinary law).

\subsection{Regional and international organisations}

Secondly, another 'classic' category of normative counteractions is that represented by norms developed at transnational level within the framework of regional or international governmental organisations. Also in this case, these counteractions integrate or modify the legal framework through legally binding instruments which correspond, in the respective regional or international organisations, to primary norms, ${ }^{16}$ secondary norms with primary value, ${ }^{17}$ and decisions of courts of last instance. ${ }^{18}$

\subsection{Non-state dimension}

Interestingly, it is possible to identify a third category of normative counteractions. They still emerge at transnational level, but this time not in a state-centric dimension, i.e. in a dimension in which nation-states represent the basic unit (see Viellechner 2012; Teubner and Fischer-

\footnotetext{
${ }^{13}$ See, as an example of norm aiming to recognise an amplification of the possibility to exercise existing fundamental rights, the right to participate in the Information society enshrined in 2001 in Article 5A of the Greek constitution, $\quad$ http://www.hellenicparliament.gr/UserFiles/f3c70a23-7696-49db-9148-f24dce6a27c8/001$156 \% 20$ aggliko.pdf.

${ }^{14}$ See, as an example of norm aiming to recognise an amplification of the possibility to exercise existing fundamental rights, the right to Internet access in Article 4 and 7 of the Brazilian Law no. 12.965/2014 (Marco Civil da Internet), https://www.publicknowledge.org/assets/uploads/documents/APPROVED-MARCO-CIVILMAY-2014.pdf.

${ }^{15}$ See, as an example of norm aiming to recognise an amplification of the possibility to exercise existing fundamental rights, the decision of the French Conseil constitutionnel no. 2009-580 DC of 10th June 2009, at 12, http://www.conseil-constitutionnel.fr/conseil-constitutionnel/root/bank/download/cc-2009580dc.pdf.

${ }^{16} \mathrm{See}$, as an example of norm aiming to recognise an amplification of the possibility to exercise existing fundamental rights, the right of persons with disabilities to access to ICT in Article 9(1) of the UN Convention on the Rights of Persons with Disabilities adopted in 2006, https://www.un.org/development/desa/disabilities/convention-on-the-rights-of-persons-with-disabilities/article9-accessibility.html.

${ }^{17}$ See, as an example of norm aiming to limit potential violation of existing fundamental rights, the introduction in the EU of new data protection principles by Regulation (EU) 2016/679 (General Data Protection Regulation).

${ }^{18} \mathrm{See}$, as an example of norm aiming to recognise an amplification of the possibility to exercise existing fundamental rights, the recognition by the European Court of Human Rights of the crucial role that Internet plays as one the principal means to exercise the right to freedom of expression, in ECtHR, Cengiz and Others v. Turkey [2015] (Applications no. 48226/10 and 14027/11), para. 49.
} 
Lescano 2004; see also Ridola 2018; Irti 2007). Consequently, they do not take the form of the binding legal instruments observed in the first two categories.

\subsubsection{Internet bills of rights}

Within this group we can undoubtedly mention the variety of instruments, many of which notlegally binding, analysed by Redeker, Gill and Gasser. In fact, in the documents of Internet bills of rights it is possible to detect all the categories of norms identified in the third section of this paper as a potential expression of normative counteractions to the alteration of the constitutional ecosystem produced by the advent of digital technology. Namely: norms aiming to recognise the enhanced possibility of individuals to exercise their fundamental rights; ${ }^{19}$ norms aiming to limit potential violations of fundamental rights; ${ }^{20}$ and norms aiming to achieve a balance of the existing powers. $^{21}$

\subsubsection{Decisions of ICANN's dispute resolution mechanism}

In the 2018 version of their paper, Redeker, Gill and Gasser explicitly exclude from their analysis the decisions of dispute resolution mechanisms of transnational organisations related to the digital environment, like ICANN. In particular, they argue that these instruments do not aim to transform Internet governance, but their objective is rather to define the rules of a particular organisation. This paper submits that this qualification does not prevent us to exclude the constitutional function of these norms. Firstly, beyond the debatable assumption that the decisions of ICANN's arbitrators do not affect Internet governance (see Bygrave 2015), it is apparent that some of the norms developed in the context of domain name dispute resolution have a constitutional character, as they directly aim to protect individual fundamental rights. For example, Teubner and Karavas mention some cases in which the decisions of the arbitrators sought to protect freedom of expression (Karavas and Teubner 2005). Secondly, it is possible to consider these decisions as an autonomous form of constitutional counteraction. In fact, in the previously mentioned cases, the arbitrators crafted their own principle of freedom of expression, by adapting an internationally recognised principle, such as the right to freedom of expression, to the specific context of domain names regulation, and without directly referring to any state-centric constitutional document (Karavas and Teubner 2005; see Teubner 2004; Karavas 2010; Viellechner 2013).

\subsubsection{Internal rules of commercial actors}

Lastly, it is possible to consider as a normative counteraction the emergence of specific norms in the internal rules of commercial actors operating in the digital environment, such as terms of use, terms of service, and binding corporate rules (see Celeste 2018b; cf. Castronova 2006). From a formal point of view, these instruments are merely contracts between private parties. However, as Suzor recognises in relation to social media's terms of service (2018), they regulate the distribution of power as constitutional documents by limiting - or legitimising - the power of dominant actors on their users. It is therefore not surprising if, following the categorisation of normative counteractions adopted in the third section of this paper, we can identify in this category of texts: norms which recognise the amplification of the possibility to exercise a fundamental right, for example establishing a right to access to digital platforms without discrimination; ${ }^{22}$ norms aiming to limit potential violations of fundamental rights, such as those specifying the extent to which users' personal data should be protected $;^{23}$ norms which attempt

\footnotetext{
19 See, e.g., Principles 3 and 8 of “The 10 Internet Rights \& Principles", http://internetrightsandprinciples.org/site/wp-content/uploads/2018/01/IRPC english 5thedition.pdf.

${ }^{20}$ See, e.g., Principle 5 of "The 10 Internet Rights \& Principles".

${ }^{21}$ See, e.g., Principle 10 of "The 10 Internet Rights \& Principles".

${ }^{22}$ See, e.g., Facebook's Principles no. 1, 3, 4, 5, 6, 7, and 10, https://www.facebook.com/principles.php.

${ }^{23}$ See, e.g., Facebook's Principles no. 2.
} 
to balance the existing powers, for example requiring digital platforms to act in a transparent way $^{24}$ or allowing users to participate in the process of amendment of their terms of service. ${ }^{25}$

\section{Conclusion}

The study of legal phenomena related to digital technology through a constitutionalist lens offers multifarious pathways of research. Constitutional theory, including both its traditional (see Loughlin 2010) and more innovative articulations (see Wiener et al. 2012), works at the same time as a 'prism' through which one can differently read ongoing phenomena (Viellechner 2012), and as a yardstick allowing the scholar to draw comparisons, perform evaluations and speculate on future developments (see Peters 2014; Kadelbach and Kleinlein 2007).

This paper adopted a constitutionalist perspective to analyse the ongoing emergence of normative counteractions vis-à-vis the legal challenges generated by the recent developments of digital technology. Some notions originating from the toolbox of constitutional theory, such as constitutionalism and constitutionalisation, appeared particularly suitable to describe and explain, what this paper defined, the current 'constitutional moment'. However, the scholarship so far handled this conceptual machinery in an apparently inconsistent way. This paper has therefore elaborated a potential way of recomposing this fragmented picture by proposing a more systematic theoretical framework.

It has been argued that digital constitutionalism identifies the ideology that adapts the values of contemporary constitutionalism to the peculiarities of the digital society. In particular, it has been contended that digital constitutionalism does not exclusively aim to limit the power of either public or private actors, as affirmed by part of the existing scholarship, but both of them. In fact, in the digital environment, private actors emerge beside nation-states as new dominant actors, thus potential guarantors and infringers of fundamental rights. Such a peculiarity therefore requires broadening the scope of the original concept of constitutionalism in order to appreciate also the existence of the power of private actors.

Moreover, it has been clarified that the notion of digital constitutionalism should not be used to term concrete normative instruments, as some scholars do. Digital constitutionalism is rather the set of values and ideals that permeate, guide and inform this series of instruments. In particular, it has been argued that digital constitutionalism imposes the emergence of a series of normative counteractions against the alterations of the constitutional equilibrium produced by digital technology.

The concept of constitutionalisation of the digital environment has been adopted to denote the ongoing process of emergence of these counteractions. Such a process, in contrast to what some scholars affirm, does not exclusively involve a formal institutionalisation or codification of norms in binding legal texts. It is a broader process, which starts from the phase of discussion and elaboration of new constitutional principles at societal level.

Finally, it has been observed that there are different kinds of normative counteractions emerging to face the challenges of digital technology. Therefore, the process of constitutionalisation of the digital environment is not unitary, but involves different categories of instruments and actors. In particular, the mapping exercise carried out at the end of this paper has shown that it is possible to identify as parts of this process not only all the instruments analysed by the existing

\footnotetext{
${ }^{24}$ See, e.g., Facebook's Principles no. 9.

${ }^{25}$ See, e.g., Facebook's Principles no. 9. Historically, Facebook went even further: in 2009 the company of Menlo Park announced for the first time to give its users the opportunity not only to comment, but even to vote the set of terms they preferred (see Zittrain 2009; Celeste 2018b).
} 
scholarship, such as ordinary law, constitutional law, and the Internet bills of rights, but also other kinds of normative responses, such as those developed at regional and international level, in the dispute resolution mechanisms of transnational organisations like ICANN, and as internal rules of commercial actors.

In light of this mapping, it is possible to notice that constitutional responses to the alterations produced by digital technology not only emerge in dimensions that we could define as 'classic' in constitutional theory, such as at the national, regional and international level, in which the nation-state still represents the central player, but also in new contexts, which are conversely dominated by private actors. This picture suggests that future research should start analysing and comparing the different forms through which the process of constitutionalisation of the digital environment is taking place, especially in the hope of better understanding the reasons why constitutional responses are materialising in non-traditional contexts outside the statecentric dimension (see Celeste 2018b; cf. Peters 2006).

\section{Acknowledgments}

I presented an earlier version of this paper at the annual BILETA Conference in Aberdeen. I am thankful to all those who attended my presentation at the final discussion of the Google Prize for their thought-provoking questions. This manuscript expands and refines my first systematic thoughts on digital constitutionalism, which I previously published in the working paper series of the Humboldt Institute for Internet and Society (HIIG). This article represents the main output of my research stay at HIIG, where I benefited from many discussions with Prof Ingolf Pernice, Dr Christian Djeffal, Dr Jörg Pohle and Julian Hölzel of the research team 'Global Constitutionalism'. Special thanks go to my colleague Louis Rolfes of the Humboldt Universität zu Berlin for his constructive criticism and for the long conversations on constitutional theory. Last, but not least, I would like to express my gratitude to my supervisor, Dr TJ McIntyre, for his valuable suggestions, and to the anonymous reviewers of IRLCT, who encouraged me to clarify complex passages of the article.

\section{Disclosure statement}

No potential conflict of interest was reported by the Author.

\section{Funding}

I gratefully acknowledge the support of the Irish Research Council Government of Ireland Postgraduate Scholarship scheme, and of the Sutherland School of Law, University College Dublin.

\section{References}

Amstutz, Marc, Andreas Abegg, and Vagias Karavas. 2007. 'Civil Society Constitutionalism: The Power of Contract Law'. Indiana Journal of Global Legal Studies 14 (2): 235-58. Balkin, Jack. 2004. 'Virtual Liberty: Freedom to Design and Freedom to Play in Virtual Worlds'. Virginia Law Review 90 (8): 2043-98.

Berman, Paul. 2000. 'Cyberspace and the State Action Debate: The Cultural Value of Applying Constitutional Norms to "Private" Regulation'. University of Colorado Law Review 71: 1263-1310. 
Blokker, Paul. 2011. 'Modern Constitutionalism and the Challenges of Complex Pluralism'. In Routledge International Handbook of Contemporary Social and Political Theory, edited by Gerard Delanty and Stephen P. Turner, 406-16. Abingdon-New York: Routledge. https://papers.ssrn.com/abstract $=1719258$.

Blume, Peter. 2010. 'Data Protection and Privacy - Basic Concept in a Changing World'. Scandinavian Studies in Law 56: 151-64.

Bobbio, Norberto. 1991. The Future of Democracy. Edited by Richard Bellamy. Translated by Roger Griffin. Minneapolis: University of Minnesota Press.

- 1996. The Age of Rights. Translated by Allan Cameron. Cambridge-Malden: Polity.

Böckenförde, Ernst-Wolfgang. 2017. Constitutional and Political Theory: Selected Writings. Edited by Mirjam Künkler and Tine Stein. Oxford Constitutional Theory. Oxford, New York: Oxford University Press.

Bonnici, Jeanne P. Mifsud. 2008. Self-Regulation in Cyberspace. Information Technology and Law Series. The Hague: T.M.C. Asser Press. //www.springer.com/us/book/9789067042673.

Bygrave, Lee A. 2015. Internet Governance by Contract. Oxford, New York: Oxford University Press.

Castorina, Emilio. 2015. 'Scienza, tecnica e diritto costituzionale'. Rivista AIC, no. 4. http://www.rivistaaic.it/la-scienza-costituzionalistica-nelle-transizioni-istituzionali-esociali.html.

Castronova, Edward. 2006. 'The Right to Play'. In The State of Play: Law, Games, and Virtual Worlds, edited by J. M. Balkin and Beth Simone Noveck, 68-85. Ex Machina. New York: New York University Press.

Celeste, Edoardo. 2018a. 'Packingham v North Carolina: A Constitutional Right to Social Media?' Cork Online Law Review 17: 116-19. https://www.corkonlinelawreview.com/single-post/2018/02/08/Packingham-v-NorthCarolina-A-Constitutional-Right-to-Social-Media.

- 2018b. 'Terms of Service and Bills of Rights: New Mechanisms of Constitutionalisation in the Social Media Environment?' International Review of Law, Computers \& Technology, 1-17. https://doi.org/10.1080/13600869.2018.1475898.

Clapham, Andrew. 2006. Human Rights Obligations of Non-State Actors. Oxford: Oxford University Press. http://www.oxfordscholarship.com/view/10.1093/acprof:oso/9780199288465.001.000 1/acprof-9780199288465.

Costanzo, Pasquale. 2012. 'Il fattore tecnologico e le sue conseguenze'. In Costituzionalismo e globalizzazione. Salerno. http://www.associazionedeicostituzionalisti.it/convegnoannuale-aic-costituzionalismo-e-globalizzazione-salerno-23-24-novembre-2012relazioni.html.

Council of Europe. 1981. 'Explanatory Report to the Convention for the Protection of Individuals with Regard to Automatic Processing of Personal Data'. Council of Europe. https://rm.coe.int/16800ca434.

Cranston, Maurice. 2014. 'Ideology'. Encyclopedia Britannica. https://www.britannica.com/topic/ideology-society.

De Minico, Giovanna. 2015. 'Towards an Internet Bill of Rights'. Loyola of Los Angeles International and Comparative Law Review 37 (1): 1-30. https://digitalcommons.lmu.edu/ilr/vol37/iss1/1.

Donnelly, Jack, and Daniel Whelan. 2018. International Human Rights. 5th ed. New York: Routledge.

Dowdle, Michael W., and Michael Wilkinson, eds. 2016. Constitutionalism beyond Liberalism. Cambridge-New York: Cambridge University Press. 
Engle, Eric. 2009. 'Third Party Effect of Fundamental Rights (Drittwirkung)'. Hanse Law Review 5 (2): 165-73.

Fischer-Lescano, Andreas. 2005. 'Redefining Sovereignty via International Constitutional Moments?' In Redefining Sovereignty: The Use of Force after the Cold War, edited by Michael Bothe, Mary Hellen O'Connel, and Natalino Ronzitti. Leiden: Brill-Nijhoff.

Fitzgerald, Brian. 1999. 'Software as Discourse? A Constitutionalism for Information Society'. Alternative Law Journal 24 (3): 144-49. . 2000. 'Software as Discourse? The Challenge for Information Law'. European Intellectual Property Review 22 (2): 47-55.

Foerstel, Herbert N. 1999. Freedom of Information and the Right to Know - The Origins and Applications of the Freedom of Information Act. Westport: Greenwood Press.

Gill, Lex, Dennis Redeker, and Urs Gasser. 2015. 'Towards Digital Constitutionalism? Mapping Attempts to Craft an Internet Bill of Rights'. Berkman Center Research Publication No. 2015-15. https://papers.ssrn.com/abstract=2687120.

Google Spain v APED. 2014 ECLI:EU:C:2014:317. ECJ.

Graber, Christoph B. 2016. 'Bottom-up Constitutionalism: The Case of Net Neutrality'. Transnational Legal Theory 7 (4): 524-52. https://doi.org/10.1080/20414005.2017.1300678.

Graber, Christoph B., and Gunther Teubner. 1998. 'Art and Money: Constitutional Rights in the Private Sphere?' Oxford Journal of Legal Studies 18: 61-74.

Grimm, Dieter. 2010. 'The Achievement of Constitutionalism and Its Prospects in a Changed World'. In The Twilight of Constitutionalism?, edited by Petra Dobner and Martin Loughlin. Oxford University Press.

Irti, Natalino. 2007. Il diritto nell'età della tecnica. Napoli: Editoriale Scientifica.

Jamart, Anne-Claire. 2014. 'Internet Freedom and the Constitutionalization of Internet Governance'. In The Evolution of Global Internet Governance, edited by Roxana Radu, Jean-Marie Chenou, and Rolf H. Weber, 57-76. Berlin, Heidelberg: Springer Berlin Heidelberg. https://doi.org/10.1007/978-3-642-45299-4_4.

Jørgensen, Rikke Frank, and Anja Møller Pedersen. 2017. 'Online Service Providers as Human Rights Arbiters'. In The Responsibilities of Online Service Providers, edited by Mariarosaria Taddeo and Luciano Floridi, 31:179-99. Cham: Springer. https://doi.org/10.1007/978-3-319-47852-4_10.

Kadelbach, Stefan, and Thomas Kleinlein. 2007. 'International Law - A Constitution for Mankind: An Attempt at a Re-Appraisal with an Analysis of Constitutional Principles Focus Section: Typisch Deutsch: Is There a German Approach to International Law: German Obsessions'. German Yearbook of International Law 50: 303-48. https://heinonline.org/HOL/P?h=hein.journals/gyil50\&i=304.

Karavas, Vagias. 2010. 'Governance of Virtual Worlds and the Quest for a Digital Constitution'. In Governance of Digital Game Environments and Cultural Diversity: Transdisciplinary Enquiries, by Christoph B. Graber and Mira Burri-Nenova. Cheltenham-Northampton: Edward Elgar Publishing.

Karavas, Vagias, and Gunther Teubner. 2005. 'Www.CompanyNameSucks.Com: The Horizontal Effect of Fundamental Rights on "Private Parties" within Autonomous Internet Law'. Constellations 12 (2): 262-82. https://doi.org/10.1111/j.13510487.2005.00415.x.

Karppi, Tero. 2018. Disconnect. University of Minnesota Press.

Kay, Richard. 1993. 'The State Action Doctrine, the Public- Private Distinction, and the Independence of Constitutional Law'. Constitutional Commentary 10: 329-60.

Kittichaisaree, Kriangsak. 2017. Public International Law of Cyberspace. Law, Governance and Technology Series. Springer International Publishing. 
Laidlaw, Emily B. 2008. 'Private Power, Public Interest: An Examination of Search Engine Accountability'. International Journal of Law and Information Technology 17 (1): 113-45. https://doi.org/10.1093/ijlit/ean018. . 2015. Regulating Speech in Cyberspace: Gatekeepers, Human Rights and Corporate Responsibility. Cambridge, United Kingdom: Cambridge University Press.

Lessig, Lawrence. 1999. Code and Other Laws of Cyberspace. New York: Basic Books.

. 2006. Code: And Other Laws of Cyberspace, Version 2.0. New York: Basic Books.

Loughlin, Martin. 2010. 'What Is Constitutionalisation?' In The Twilight of Constitutionalism?, edited by Petra Dobner and Martin Loughlin. Oxford University Press.

Mayer-Schönberger, Viktor, and John Crowley. 2006. 'Napster's Second Life?: The Regulatory Challenges of Virtual World'. Northwestern University Law Review 100 (4): $1775-1826$.

McIlwain, Charles Howard. 2007. Constitutionalism: Ancient and Modern. Indianapolis: Amagi, originally published by Cornell University Press, 1947,.

Medeiros, Francis Augusto, and Lee A. Bygrave. 2015. 'Brazil's Marco Civil Da Internet: Does It Live up to the Hype?' Computer Law \& Security Review 31 (1): 120-30. https://doi.org/10.1016/j.clsr.2014.12.001.

Milewicz, Karolina. 2009. 'Emerging Patterns of Global Constitutionalisation: Towards a Conceptual Framework'. Indiana Journal of Global Legal Studies 16 (2): 413-36.

Musiani, Francesca, Elena Pavan, and Claudia Padovani. 2009. 'Investigating Evolving Discourses on Human Rights in the Digital Age: Emerging Norms and Policy Challenges'. International Communication Gazette 72 (4): 359-78. https://doi.org/10.1177/1748048510362618.

Mustonen, Juha, ed. 2006. 'The World's First Freedom of Information Act - Andres Chydenius' Legacy Today'. Andres Chydenius Foundation. http://www.chydenius.net/pdf/worlds_first_foia.pdf.

Padovani, Claudia, and Mauro Santaniello. 2018. 'Digital Constitutionalism: Fundamental Rights and Power Limitation in the Internet Eco-System'. International Communication Gazette 80 (4): 295-301. https://doi.org/10.1177/1748048518757114.

Pernice, Ingolf. 2014. 'Die Verfassung der Internetgesellschaft: Zur Rolle von Staat und Verfassung im Zuge der digitalen Revolution (The Constitution of the Digital Society: State and Constitution in the Course of the Digital Revolution)'. In Den Verfassungsstaat nachdenken. Eine Geburtstagsgabe, edited by Alexander Blankenagel, 171-208. HIIG Discussion Paper Series No 2017-03. Berlin: Duncker \& Humblot. https://papers.ssrn.com/abstract=2964926. . 2016. 'Global Constitutionalism and the Internet. Taking People Seriously.' In Law Beyond the State: Pasts and Futures, edited by Stefan Kadelbach and Rainer Hofmann, 151-204. Frankfurt/New York: Campus Verlag. http://ssrn.com/abstract=2576697.

Peters, Anne. 2006. 'Compensatory Constitutionalism: The Function and Potential of Fundamental International Norms and Structures'. Leiden Journal of International Law 19: 579-610. https://papers.ssrn.com/abstract=1564125. . 2014. 'Global Constitutionalism'. In The Encyclopedia of Political Thought, edited by Michael T. Gibbons, 1484-87. John Wiley \& Sons. https://doi.org/10.1002/9781118474396.wbept0421.

Preuss, Ulrich K. 2010. 'Disconnecting Constitutions from Statehood: Is Global Constitutionalism a Viable Concept?' In The Twilight of Constitutionalism?, edited by Petra Dobner and Martin Loughlin. Oxford University Press. 
Redeker, Dennis, Lex Gill, and Urs Gasser. 2018. 'Towards Digital Constitutionalism? Mapping Attempts to Craft an Internet Bill of Rights'. International Communication Gazette 80 (4): 302-19. https://doi.org/10.1177/1748048518757121.

Ridola, Paolo. 2018. 'Il costituzionalismo e lo stato costituzionale'. Nomos, no. 2: 16. http://www.nomos-leattualitaneldiritto.it/wp-content/uploads/2018/05/Ridola.pdf.

Rodotà, Stefano. 2010. 'Una Costituzione per Internet?' Politica Del Diritto, no. 3: 337-51.

Rosanvallon, Pierre. 2006. La Contre-Démocratie. La politique à l'âge de la défiance. Paris: Le Seuil.

Rubenfeld, Jed. 2004. 'Unilateralism and Constitutionalism'. New York University Law Review 79 (6): 1971-2028.

Saint-Exupéry, Antoine de. 1943. The Little Prince. Strelbytskyy Multimedia Publishing.

Sajó, András. 1999. Limiting Government: An Introduction to Constitutionalism. Budapest ; New York: Central European University Press.

Sartor, Giovanni. 2017. 'Human Rights and Information Technologies'. In The Oxford Handbook of Law, Regulation and Technology, edited by Roger Brownsword, Eloise Scotford, and Karen Yeung, 424-50. Oxford, New York: Oxford University Press. http://www.oxfordhandbooks.com/view/10.1093/oxfordhb/9780199680832.001.0001/ oxfordhb-9780199680832-e-79.

Simoncini, Andrea. 2016. 'The Constitutional Dimension of the Internet: Some Research Paths'. EUI Working Papers No. 2016/16. https://doi.org/10.2139/ssrn.2781496.

Slaughter, Anne-Marie, and William Burke-White. 2002. 'An International Constitutional Moment Focus: September 11, 2001--Legal Response to Terror'. Harvard International Law Journal 43: 1-22. https://heinonline.org/HOL/P?h=hein.journals/hilj43\&i=7.

Suzor, Nicolas. 2010. 'Digital Constitutionalism and the Role of the Rule of Law in the Governance of Virtual Communities'. Phd, Queensland University of Technology. https://eprints.qut.edu.au/37636/. . 2018. 'Digital Constitutionalism: Using the Rule of Law to Evaluate the Legitimacy of Governance by Platforms'. Social Media + Society 4 (3): 2056305118787812. https://doi.org/10.1177/2056305118787812.

Suzor, Nicolas, Tess Van Geelen, and Sarah Myers West. 2018. 'Evaluating the Legitimacy of Platform Governance: A Review of Research and a Shared Research Agenda'. International Communication Gazette 80 (4): 385-400. https://doi.org/10.1177/1748048518757142.

Teubner, Gunther. 1993. Law as an Autopoietic System. The European University Institute Press Series. Oxford, UK ; Cambridge, USA: Blackwell. 2004. 'Societal Constitutionalism; Alternatives to State-Centred Constitutional Theory?' In Transnational Governance and Constitutionalism. International Studies in the Theory of Private Law, edited by Christian Joerges, Inger-Johanne Sand, and Gunther Teubner, 3-28. Oxford-Portland: Hart.

- 2012. Constitutional Fragments: Societal Constitutionalism and Globalization. Oxford: Oxford University Press.

Teubner, Gunther, and Andreas Fischer-Lescano. 2004. 'Regime-Collisions: The Vain Search for Legal Unity in the Fragmentation of Global Law'. Michigan Journal of International Law 25: 999-1046. https://papers.ssrn.com/abstract $=873908$.

Viellechner, Lars. 2012. 'Constitutionalism as a Cipher : On the Convergence of Constitutionalist and Pluralist Approaches to the Globalization of Law'. Goettingen Journal of International Law. https://doi.org/10.3249/1868-1581-4-2-viellechner. . 2013. Transnationalisierung des Rechts. Weilerswist: Velbrück. 
Waldron, Jeremy. 2010. 'Constitutionalism: A Skeptical View'. Philip A. Hart Memorial Lecture, March. https://scholarship.law.georgetown.edu/hartlecture/4.

Walker, Neil. 2003. 'Postnational Constitutionalism and the Problem of Translation'. In European Constitutionalism Beyond the State, edited by J. H. H. Weiler and Marlene Wind, 27-54. Cambridge-New York: Cambridge University Press.

Weiler, J. H. H., and Marlene Wind, eds. 2003. European Constitutionalism beyond the State. Cambridge-New York: Cambridge University Press.

Wiener, Antje. 2003. 'Editorial: Evolving Norms of Constitutionalism'. European Law Journal 9 (1): 1-13. https://doi.org/10.1111/1468-0386.00167.

Wiener, Antje, Anthony F. Lang, James Tully, Miguel Poiares Maduro, and Mattias Kumm. 2012. 'Global Constitutionalism: Human Rights, Democracy and the Rule of Law'. Global Constitutionalism 1 (01): 1-15. https://doi.org/10.1017/S2045381711000098.

Yilma, Kinfe Micheal. 2017. 'Digital Privacy and Virtues of Multilateral Digital Constitutionalism - Preliminary Thoughts'. International Journal of Law and Information Technology 25 (2): 115-38. https://doi.org/10.1093/ijlit/eax001.

Zittrain, Jonathan. 2009. 'A Bill of Rights for the Facebook Nation'. The Chronicle of Higher Education (blog). 20 April 2009.

https://www.chronicle.com/blogs/wiredcampus/jonathan-zittrain-a-bill-of-rights-forthe-facebook-nation/4635. 